\title{
PENGARUH CUSTOMER RELATIONSHIP MANAGEMENT DAN KUALITAS PELAYANAN TERHADAP LOYALITAS NASABAH KREDIT KOMERSIL PADA BANK NAGARI SUMATERA BARAT CABANG PAINAN
}

\author{
Lira Anggraini, Alfian \\ STIE "KBP" PADANG \\ liraanggraini210@gmail.com
}

\begin{abstract}
This study aims to determine the effect of customer relationship management and service quality to loyalty of commercial credit customers at Nagari Bank West Sumatera Painan Branch. The sample used counted 95 respondents, sampling technique using accidental sampling method. Data were collected using questionnaire, while data analysis technique was done by using multiple linear regression analysis. The results showed that based on Persial Test ( $t$ test) obtained: a) service quality variable has a positive effect 0,805 < 1,985 and not significant 0,423>0,05 to customer loyalty. b) customer satisfaction variables have a positive effect of 0,218 $<1,985$ and not significant 0,828 >0,05 to customer loyalty. c) variable of reliability have positive effect 2,254>1,985 and significant 0,027 < 0,05 to customer loyalty. d) Responsiveness variable has positive effect $8.173>1.985$ and significant $0.000<0,05$ to customer loyalty. $e$ ) the assurance variable has a positive effect $0,983<1,985$ and not significant 0,328 >0,05 to customer loyalty. f) empathy variables have negative effect $-2,615>1,985$ and significant $0,011<$ 0,05 to customer loyalty. $g$ ) tangible variable has a positive effect of 2,791 >1,985 and significant 0,006 <0,05 to customer loyalty. From this research, the value of $R^{2}$ is 0,598, it means that 59,8\% influenced by service quality variable, customer satisfaction, reliability, responsiveness, assurance, empathy, tangible and the rest influenced by other variables.
\end{abstract}

Keywords: Quality of Service, Customer Satisfaction, Reliability, Responsiveness, Assurance, Empathy, Tangible.

\section{PENDAHULUAN}

Perkembangan dunia saat ini sangatlah pesat, yang menciptakan persaingan yang sangat ketat. Untuk itu dalam memajukan perekonomian suatu daerah peranan perbankan sangat penting dalam mewujudkan perekonomian yang maju. Sebagai perusahaan yang bergerak di bidang keuangan, perbankan menempati posisi yang strategis dalam pembangunan perekonomian. Seperti yang kita ketahui semua sektor yang berhubungan dengan berbagai kegiatan keuangan selalu membutuhkan jasa bank. Salah satu dari peranan bank adalah sebagai lembaga kepercayaan yang menghimpun dana yang berasal dari masyarakat dan disalurkan kembali kepada masyarakat semata-mata hanya untuk meningkatkan pembangunan. Dana yang disalurkan kepada masyarakat yang berupa kredit ini diharapkan mampu meningkatkan perekonomian, khususnya pada masyarakat yang taraf perekonomiannya menengah kebawah karena kredit ini sangat membantu untuk membiayai usahanya.

Menurut Kotler dan Keller (2009) dalam jurnal (Imasari \& Nursalin, 2011) mendefinisikan loyalitas pelanggan sebagai "the long term success of the 
particular brand is not based on the number of consumer who purchase it only once, but on the number who become repeat purchase". Melalui definisi ini, Kotler dan Keller menjelaskan bahwa konsumen akan loyal diukur melalui tiga hal dibawah ini yaitu: merekomendasikan orang lain untuk membeli atau mereferensikan kepada orang lain (Word of mouth), menolak menggunakan produk lain atau menunjukkan kekebalan terhadap tarikan dari pesaing (Reject another), berapa sering melakukan pembelian ulang (Repeat purchasing). Tiga hal ini sangat berperan dalam membentuk tingkat loyalitas pelanggan, penelitian atas loyalitas dilihat dari keinginan untuk membeli kembali dan menyampaikan atau merekomendasikan dengan cara informasi dari mulut kemulut (word of mouth).

Upaya untuk menumbuhkan loyalitas pelanggan dapat dilakukan dengan beberapa strategi pemasaran, salah satunya adalah dengan customer relationship management (CRM). Menurut Newell (2009) dalam jurnal (Imasari \& Nursalin, 2011), Customer Relationship Management (CRM) adalah sebuah modifikasi dan pembelajaran perilaku konsumen setiap waktu dari setiap interaksi, perlakuan terhadap pelanggan dan membangun kekuatan antara konsumen dan perusahaan. Dapat disimpulkan bahwa customer relationship management (CRM) adalah suatu proses mengenali perilaku konsumen pada setiap waktu dari setiap interaksi dan perlakuan perusahaan terhadap pelanggan serta bagaimana membangun kekuatan antara pelanggan dan perusahaan.

Hal lain yang dapat mempengaruhi tingkat loyalitas pelanggan yaitu kualitas pelayanan. Fenomena perkembangan dunia bisnis yang semakin pesat dewasa ini menimbulkan bertambahnya jumlah macam-macam produk kredit komersil yang sejenis ditawarkan oleh sektor perbankan. Perbankan harus mampu memberikan kualitas pelayanan yang baik. Kualitas pelayanan yang baik akan meningkatkan loyalitas nasabah terhadap perbankan tersebut. Selain itu, dengan memperhatikan akan pentingnya pelayanan konsumen sebagai salah satu alat persaingan, suatu perusahaan harus mampu mengetahui lebih dahulu pengertian dari kualitas jasa (service qualiy).

Kredit komersil merupakan kredit yang pada umumnya diberikan bagi nasabah yang ingin memperluas usahanya dengan melakukan permohonan kredit dengan berbagai fasilitas kredit yang telah disediakan. Dengan adanya kredit komersil ini, diharapkan para nasabah yang mempunyai kemampuan dalam mengembangkan usahanya dapat menciptakan lapangan pekerjaan dan membantu perekonomian indonesia sesuai dengan prosedur dan persyaratan yang telah ditetapkan sehingga terus terjalin hubungan kerjasama antar bank dan debitur. Berdasarkan jenisnya, produk kredit komersil terbagi atas tiga yaitu kredit investasi, kredit modal kerja dan kredit rekening koran. Proses dalam penyaluran kredit adalah mengisi formulir pengajuan permohonan lengkap dengan dokumen dan persyaratan yang telah ditentukan, melakukan verifikasi data nasabah, melakukan analisa debitur dan survey lapangan, wawancara, rekomendasi kredit, keputusan kredit dari kepala cabang, perjanjian kredit, melakukan posting dan pemindahbukuan dan terakhir realisasi kredit.

Namun disini kredit komersil Bank Nagari Cabang Painan memiliki kendala dimana kurangnya penerapan customer relationship management dan mutu kualitas pelayanan yang diterapkan oleh bank, mengakibatkan para pemakai jasa perbankan terutama para kalangan atas sebagai pemakai jasa perbankan 
semakin kritis karena mengetahui buying power yang mereka miliki cukup tinggi. Apalagi semakin banyaknya perusahaan jasa lain yang bergerak dibidang yang sama yang lebih memberikan penerapan customer relationship management dan mutu kualitas pelayanan yang lebih baik, baik dari segi fasilitas maupun dari segi petugas kreditnya. Oleh karena itu, apabila suatu sektor perbankan mendambakan daya saing yang tinggi, dituntut untuk dapat memenuhi apa yang dibutuhkan oleh para pemakai jasanya karena nasabah pada masa sekarang lebih banayk menuntut akan kebutuhan finansialnya.

Berikut adalah data perkembangan pertumbuhan kredit komersil di Bank Nagari Sumatera Barat Cabang Painan periode tahun 2012-2016.

\section{Tabel 1}

Data Perkembangan Pertumbuhan Kredit Komersil Bank Nagari Sumatera Barat Cabang Painan

\begin{tabular}{|c|c|c|}
\hline Tahun & Jumlah Nasabah Kredit & Baki Debet (miliaran rupiah) \\
\hline 2012 & 2.160 & 122.179 \\
\hline 2013 & 2.164 & 125.818 \\
\hline 2014 & 2.200 & 129.068 \\
\hline 2015 & 1.775 & 89.187 \\
\hline 2016 & 1.768 & 79.475 \\
\hline
\end{tabular}

Sumber : PT. Bank Nagari Cabang Painan

Dari tabel 1menunjukkan bahwa data perkembangan pertumbuhan kredit komersil mengalami penurunan pada dua tahun terakhir periode 2015-2016. Pada tahun 2012 dengam jumlah nasabah 2.160 orang baki debet sebesar 122.179 miliaran, pada tahun 2013 jumlah nasabah 2.164 orang baki debet sebesar 125.818 miliaran mengalami kenaikan, pada tahun 2014 jumlah nasabah 2.200 orang baki debet sebesar 129.068 miliaran mengalami kenaikan, pada tahun 2015 jumlah nasabah 1.775 orang baki debet sebesar 89.187 miliaran mengalami penurunan lumayan tinggi, pada tahun 2016 jumlah nasabah 1.768 orang baki debet sebesar 79.475 miliaran masih mengalami penurunan. Bisa kita lihat dari persentasi penjualannya yang menurun pada dua tahun terakhir periode 2015-2016. Hal ini diduga disebabkan karena kurangnya hubungan antara pihak Bank Nagari dengan nasabah, minimnya penerapan CRM, mutu kualitas pelayanan yang kurang memuaskan seperti sarana dan prasarana, dan adanya keluhan dari nasabah tentang kebersihan ruangan Bank Nagari, serta kurang tanggapnya para petugas kredit dalam melayani nasabah yang sedang membutuhkan jasanya. Oleh karena itu, khususnya pihak produk kredit komersil Bank Nagari harus lebih giat lagi dalam menerapkan customer relationship management dan mutu kualitas pelayanan agar produk kredit komersil itu bisa diminati oleh para pemakai jasanya dan perkembangan pertumbuhannya meningkat lagi setiap tahunnya. Bank Nagari dalam menjalankan usahanya harus selalu memantau perubahan perilaku nasabah sehingga dapat mengantisipasi perubahan perilaku tersebut, karena pada hakikatnya dengan mengetahui dan memahami sifat nasabah secara baik sehingga produk yang ditawarkan menjadi sangat diminati oleh nasabah dan nasabah loyal terhadap produk yang ditawarkan. Pemilihan loyalitas nasabah terhadap produk pada dasarnya karena adanya manfaat dan mutu yang diberikan oleh produk tersebut, selain itu loyalitas nasabah juga dipengaruhi oleh penerapan customer relationship management dan kualitas pelayanan produk tersebut. 


\section{Pengertian Loyalitas}

Menurut Griffin (2003) dalam jurnal (Imasari \& Nursalin, 2011), loyalitas pelanggan adalah aktivitas dalam melakukan pembelian secara teratur, membeli diluar lini produk atau jasa, merekomendasikan produk lain, menunjukkan kekebalan dari daya tarik produk sejenis dari pesaing. Dapat disimpulkan bahwa loyalitas pelanggan adalah pelanggan yang melakukan pembelian secara teratur pada produk atau jasa serta merekomendasikan produk atau jasa kepada orang lain dengan menunjukkan kekebalan dari daya tarik produk sejenis dari kompetitior.

\section{Pengertian Keputusan Pembelian}

Pelanggan yang loyal merupakan aset penting bagi perusahaan, hal ini dapat dilihat dari karakteristik yang dimilikinya, sebagaimana diungkapkan oleh Griffin (2005) dalam jurnal (Suwitho, 2014) pelanggan yang loyal memiliki karakteristik sebagai berikut :

1. Melakukan pembelian secara teratur atau pembelian ulang.

2. Membeli diluar lini produk atau jasa (pembelian antar lini produk.

3. Merekomendasikan produk atau jasa kepada orang lain.

4. Menunjukkan kekebalan dari daya tarik produk atau jasa sejenis.

\section{Tahapan dan Tingkatan Loyalitas}

Untuk menjadi pelanggan yang mempunyai sifat loyal terdapat beberapa tahapan yang harus dilalui oleh pelanggan. Secara sederhana saat pelanggan membeli produk, pelanggan harus mempunyai suatu keyakinan dalam dirinya tentang produk tersebut. Menurut Hill yang diterjemahkan oleh Ratih Hurriyati (2010) dalam jurnal (Ridwan, n.d.) menjelaskan tahapan loyalitas terbagi menjadi enam tahap, yaitu :

1. Suspect

2. Prospect

3. Customer

4. Clients

5. Advocates

6. Partners

Sedangkan tingkatan pelanggan menuju loyalitas menurut Syaifuddin Chan (2010) dalam (Ridwan, n.d.) dibagi menjadi empat tahapan, yaitu :

1. Emas $($ Gold $)$

2. Perak (Silver)

3. Perunggu (Bronze)

4. Besi (Iron)

\section{Tipe Loyalitas}

Menurut Jill Griffin dalam bukunya Customer Loyalty (dalam Mokodongan 2010) dalam jurnal (Wijayanti, n.d.), ada empat macam tipe loyalitas yaitu :

1. Loyalitas Premium (Premium Loyalty)

2. Loyalitas Lemah (Inertia Loyalty)

3. Loyalitas Tersembunyi (Latent Loyalty)

4. Tidak Loyal (No Loyalty) 


\section{Prinsp-Prinsip Loyalitas}

Kottler (2005) dalam (Kasanah et al., 2016) mengemukakan bahwa pada hakekatnya loyalitas pelanggan dapat diibaratkan sebagai perkawinan perusahaan dengan publik (terutama pelanggan inti). Jalinan relasi ini akan berlangsung bila dilandasi dengan sepuluh prinsip pokok loyalitas pelanggan sebagai berikut :

1. Kemitraan

2. Nilai tambah

3. Sikap saling percaya

4. Keterbukaan

5. Pemberian bantuan secara aktif dan konkret

6. Tindakan berdasarkan semua unsur antusiasme konsumen.

7. Fokus pada hal - hal yang tidak terduga

8. Kedekatan dengan pelanggan internal dan eksternal

9. Pembinaan relasi dengan pelanggan pada tahap purna beli

10. Antisipasi kebutuhan dan harapan pelanggan dimasa datang.

\section{Idikator Loyalitas Pelanggan}

Tjiptono dalam Sangadji dan Sopiah (2013) dalam (Kasanah et al., 2016) mengemukakan enam indikator yang bisa digunakan untuk mengukur loyalitas pelanggan, yaitu :

1. Pembelian berulang

2. Kebiasaan mengonsumsi merek

3. Rasa suka yang besar pada merek

4. Ketetapan pada merek

5. Keyakinan bahwa merek tertentu merek yang terbaik

6. Perekomendasian merek kepada orang lain

\section{Pengertian Customer Relatonship Management}

Menurut Kotler dan Keller (2009) dalam jurnal (Imasari \& Nursalin, 2011), Customer Relationship Management (CRM) merupakan proses mengelola informasi secara rinci tentang masing-masing pelanggan dan secara cermat mengelola semua "titik sentuh" pelanggan demi memaksimalkan kesetiaan pelanggan. Dapat disimpulkan customer relationship management (CRM) adalah suatu proses mengelola informasi secara detail pada masing-masing pelanggan dan secara cermat mengelola seluruh titik sentuh pelanggan untuk memaksimalkan loyalitas pelanggan.

\section{Faktor Yang Mempengaruhi Customer Relationship Management}

Dalam menerapkan Customer Relationship Management (CRM) ada beberapa faktor yang mempengaruhinya. Menurut Robinette (2001) dalam jurnal (Febrianingtyas, Arifin, Fanani, Administrasi, \& Brawijaya, n.d.) menjelaskan bahwa ada empat faktor yang mempengaruhi Customer Relationship Management (CRM), antara lain keuntungan bersama, komitmen, kebenaran dan komunikasi.

\section{Indikator Customer Relationship Management}

Menurut Handoko dan Marliyana (2003) dalam jurnal (Kusnadi, 1945), Indikator dari Customer Relationship Management (CRM) adalah antara lain :

1. Dicapainya efisiensi.

2. Mutu pelayanan.

3. Kepuasan pelanggan.

4. Tersedianya data atau pengetahuan mengenai perilaku pelanggan. 


\section{Kualitas Pelayanan}

Menurut Pranama dan Rastini (2013) dalam (Kasanah et al., 2016) kualitas pelayanan merupakan suatu bentuk penilaian, terhadap tingkat layanan yang diberikan oleh suatu perusahaan

\section{Faktor Yang Mempengaruhi Kualitas Pelayanan}

Menurut tjiptono (2003) dalam (Ayu et al., 2014) mengemukakan bahwa ada empat faktor yang mempengaruhi kualitas pelayanan, antara lain menjaga dan memperhatikan, spontanita, penyelesaian masalah dan perbaikan.

1. Menjaga dan memperhatikan

2. Spontanita

3. Penyelesaian masalah

4. Perbaikan

\section{Indikator Kualitas Pelayanan}

Menurut Zeithalm, Bitner dan Gremler (dalam Jesicca Lauw dan Kunto 2013) dalam jurnal (Santoso \& Oetomo, 2013), adapun indikator kualitas pelayanan yaitu :

1. Reliability (keandalan)

2. Responsiveness (cepat tanggap)

3. Assurance (jaminan)

4. Empathy (empati)

5. Tangible (berwujud)

\section{METODE PENELTIAN}

\section{Jenis penelitian}

Jenis penelitian ini adalah penelitian yang bersifat deskriptif dengan menggunakan pendekatan kuantitatif. Menurut Sugiyono (2015) pendekatan kuantitatif yaitu salah satu metode penelitian dimana data penelitian berupa angka-angka dan analisis menggunakan statistik.

Dalam penelitian ini yang menjadi objek yang akan diteliti adalah nasabah kredit komersil Bank Nagari Sumatera Barat Cabang Painan yang berlokasi di Jl. H. Ilyas Yakub Painan, Kabupaten Pesisir Selatan, Sumatera Barat.

\section{Populasi dan Sampel}

Menurut Sugiyono (2015) populasi adalah wilayah generalisasi yang terdiri atas subjek atau objek yang mempunyai kuantitas dan karakteristik tertentu yang ditetapkan oleh peneliti untuk dipelajari dan kemudian ditarik kesimpulannya.

Dalam penelitian ini yang menjadi populasi adalah nasabah kredit komersil pada Bank Nagari Sumatera Barat Cabang Painan yang pada posisi akhir tahun 2016 berjumlah sebanyak 1.768 orang.

\section{Sampel}

Menurut Sugiyono (2015) sampel adalah bagian dari jumlah dan karakteristik yang dimiliki oleh populasi, untuk itu sampel yang diambil harus betul-betul representative (mewakili).

besarnya sampel penelitian adalah:

$$
n=\frac{1768}{1+1768(0,10)^{2}}=\frac{1768}{18,68}=95 \text { orang }
$$

jadi besar sampel penelitian adalah 95 orang 
ANALISA DAN PEMBAHASAN

Analisis Regresi Linear Berganda

Coefficients $^{\mathrm{a}}$

Tabel 2

Koefisien Regresi

\begin{tabular}{|c|c|c|c|c|c|}
\hline \multirow[b]{2}{*}{ Model } & \multicolumn{2}{|c|}{$\begin{array}{l}\text { Unstandardized } \\
\text { Coefficients }\end{array}$} & \multirow{2}{*}{$\begin{array}{c}\begin{array}{c}\text { Standardized } \\
\text { Coefficients }\end{array} \\
\text { Beta } \\
\end{array}$} & \multirow[b]{2}{*}{$\mathbf{T}$} & \multirow[b]{2}{*}{ Sig. } \\
\hline & B & Std. Error & & & \\
\hline (Constant) & 2.627 & 1.972 & & 1.332 & .186 \\
\hline $\mathrm{X} 1$ & .064 & .080 & .073 & .805 & .423 \\
\hline $\mathrm{X} 2$ & .019 & .085 & .020 & .218 & .828 \\
\hline $\mathrm{X} 3$ & .153 & .068 & .170 & 2.254 & .027 \\
\hline $\mathrm{X} 4$ & .561 & .069 & .611 & 8.173 & .000 \\
\hline $\mathrm{X} 5$ & .064 & .065 & .070 & .983 & .328 \\
\hline X6 & -.153 & .059 & -.185 & -2.615 & .011 \\
\hline $\mathrm{X} 7$ & .168 & .060 & .197 & 2.791 & .006 \\
\hline
\end{tabular}

a. Dependent Variable: Y

Sumber : data olahan 2018

Berdasarkan tabel maka ringkasan hasil pengujian dapat diformulasikan persamaan regresinya sebagai berikut.

$\mathrm{Y}=2.627+0,064 \mathrm{X} 1+0,019 \mathrm{X} 2+0,153 \mathrm{X} 3+0,561 \mathrm{X} 4+0,064 \mathrm{X} 5-0,153 \mathrm{X} 6$ $+0,168 \times 7$

Dari persamaan regresi diatas, dapat diinterprestasikan sebagai berikut :

1. $a=2.627$ artinya tanpa variabel bebas (variabel X) maka loyalitas nasabah kredit komersil pada Bank Nagari Sumatera Barat Cabang Painan adalah 2.627 dengan asumsi variabel bebas yaitu mutu pelayanan, kepuasan pelanggan, reliability (keandalan), responsiveness (daya tanggap), assurance (jaminan), empathy (empati), tangible (berwujud) tidak mengalami perubahan.

2. $\mathrm{b} 1=$ koefisien regresi 0.064 menunjukan bahwa setiap variabel mutu pelayanan bertambah sebanyak 1 poin, maka peningkatan loyalitas nasabah kredit komersil pada Bank Nagari Sumatera Barat Cabang Painan bertambah sebesar 0.064 dengan asumsi variabel mutu pelayanan dianggap tetap.

3. $\mathrm{b} 2=$ koefisien regresi 0.019 menunjukan bahwa setiap variabel kepuasan pelanggan bertambah sebanyak 1 poin, maka peningkatan loyalitas nasabah kredit komersil pada Bank Nagari Sumatera Barat Cabang Painan bertambah sebesar 0.019 dengan asumsi variabel kepuasan pelanggan dianggap tetap.

4. $b 3=$ koefisien regresi 0.153 menunjukan bahwa setiap variabel reliability (keandalan) bertambah sebanyak 1 poin, maka peningkatan loyalitas nasabah kredit komersil pada Bank Nagari Sumatera Barat Cabang Painan 
bertambah sebesar 0.153 dengan asumsi variabel reliability (keandalan) dianggap tetap.

5. $\mathrm{b} 4=$ koefisien regresi 0.561 menunjukan bahwa setiap variabel responsiveness (daya tanggap) bertambah sebanyak 1 poin, maka peningkatan loyalitas nasabah kredit komersil pada Bank Nagari Sumatera Barat Cabang Painan bertambah sebesar 0.561 dengan asumsi variabel responsiveness (daya tanggap) dianggap tetap.

6. b5= koefisien regresi 0.064 menunjukan bahwa setiap variabel assuranse (jaminan) bertambah sebanyak 1 poin, maka peningkatan loyalitas nasabah kredit komersil pada Bank Nagari Sumatera Barat Cabang Painan bertambah sebesar 0.064 dengan asumsi variabel assuranse (jaminan) dianggap tetap.

7. b6= koefisien regresi -0.153 menunjukan bahwa setiap variabel empathy (empati) berkurang sebanyak 1 poin, maka pengurangan loyalitas nasabah kredit komersil Bank Nagari Sumatera Barat Cabang Painan berkurang sebesar -0.153 dengan asumsi variabel empathy (empati) dianggap tidak tetap.

8. b7= koefisien regresi 0.168 menunjukan bahwa setiap variabel tangible (berwujud) bertambah sebanyak 1 poin, maka peningkatan loyalitas nasabah kredit komersil Bank Nagari Sumatera Barat Cabang Painan bertambah sebesar 0.168 dengan asumsi variabel tangible (berwujud) dianggap tetap.

\section{Uji Hipotesis}

\section{Uji F}

\section{Tabel 3}

Hasil Uji F

\begin{tabular}{|c|c|c|c|c|}
\hline Variabel & F-hit & Sig & Alpha & Kesimpulan \\
\hline Mutu Pelayanan, Kepuasan & 20.980 & $.000^{\mathrm{a}}$ & 0,5 & Signifikan \\
Pelanggan, & & & & \\
Reliability(Keandalan), & & & & \\
Responsiveness (Daya & & & & \\
Tanggap), Assurance \\
(Jaminan), & & & & \\
$\begin{array}{c}\text { Empathy(Empati),Tangible } \\
\text { (Berwujud) }\end{array}$ & & & & \\
\hline
\end{tabular}

Sumber : data olahan 2018

Berdasarkan hasil ringkasan hasil uji $\mathrm{F}$ yang di kemukakan pada tabel 4.27 diketahui variabel mutu pelayanan, kepuasan pelanggan, reliability (keandalan), responsiveness (daya tanggap), assurance (jaminan), empathy (empati), tangible (berwujud) di temukan nilai sig atau probality sebesar 0,05 dalam melakukan penelitian, penulis melakukan tingkat kesalahan maksimal (level of signifikan) sebesar 5\% berarti nilai F-statistik untuk variabel lainnya $0,000<\alpha=0,5$ maka loyalitas nasabah adalah Ha diterima dan Ho ditolak. Berarti dapat disimpulkan bahwa variabel mutu pelayanan, kepuasan pelanggan, reliability (keandalan), responsiveness (daya tanggap), assurance (jaminan), empathy (empati), tangible (berwujud) memiliki pengaruh yang signifikan terhadap loyalitas nasabah kredit komersil pada Bank Nagari Sumatera Barat Cabang Painan secara serempak. 


\section{Uji T}

Tabel 4

Hasil Uji t

\begin{tabular}{|l|c|c|c|c|}
\hline \multicolumn{1}{|c|}{ Variabel } & t-hit & Sig & Alpha & Kesimpulan \\
\hline Mutu Pelayanan & .805 & 0.423 & 0,05 & Tidak Signifikan \\
\hline $\begin{array}{l}\text { Kepuasan } \\
\text { Pelanggan }\end{array}$ & .218 & 0.828 & 0,05 & Tidak Signifikan \\
\hline $\begin{array}{l}\text { Reliability } \\
\text { (Keandalan) }\end{array}$ & 2.254 & 0.027 & 0,05 & Signifikan \\
\hline $\begin{array}{l}\text { Responsiveness } \\
\text { (Daya Tanggap) }\end{array}$ & 8.173 & 0.000 & 0,05 & Signifikan \\
\hline $\begin{array}{l}\text { Assurance } \\
\text { (Jaminan) }\end{array}$ & .983 & 0.328 & 0,05 & Tidak Signifikan \\
\hline Empathy (Empati) & -2.615 & 0.011 & 0,05 & Signifikan \\
\hline $\begin{array}{l}\text { Tangible } \\
\text { (Berwujud) }\end{array}$ & 2.791 & 0.006 & 0,05 & Signifikan \\
\hline
\end{tabular}

Sumber : data olahan 2018

Berdasarkan ringkasan hasil uji $\mathrm{t}$ seperti yang dikemukakan pada tabel diketahui :

1. Berdasarkan hasil pengujian uji $\mathrm{T}$ untuk variabel mutu pelayanan diatas dapat disimpulkan bahwa nilai $\mathrm{T}$ hitung mutu pelayanan terhadap loyalitas nasabah sebesar 0,805 dan $\mathrm{T}$ tabel 1,985 dengan signifikan 0,423>0,05. Hal ini berarti $\mathrm{T}$ hitung lebih kecil dari $\mathrm{T}$ tabel dan signifikan $>0,05$ maka Ho ditolak dan Ha diterima, artinya variabel mutu pelayanan berpengaruh tidak signifikan terhadap loyalitas nasabah kredit komersil pada Bank Nagari Sumatera Barat Cabang Painan.

2. Berdasarkan hasil pengujian uji $\mathrm{T}$ untuk variabel kepuasan pelanggan diatas dapat disimpulkan bahwa nilai $\mathrm{T}$ hitung kepuasan pelanggan terhadap loyalitas nasabah sebesar 0,218 dan $\mathrm{T}$ tabel 1,985 dengan signifikan 0,828 > 0,05. Hal ini berarti $\mathrm{T}$ hitung lebih kecil dari $\mathrm{T}$ tabel dan signifikan $>0,05$ maka Ho ditolak dan Ha diterima, artinya variabel kepuasan pelanggan berpengaruh tidak signifikan terhadap loyalitas nasabah kredit komersil pada Bank Nagari Sumatera Barat Cabang Painan.

3. Berdasarkan hasil pengujian uji T untuk variabel reliability (keandalan) diatas dapat disimpulkan bahwa nilai $\mathrm{T}$ hitung reliability (keandalan) terhadap loyalitas nasabah sebesar 2,254 dan $\mathrm{T}$ tabel 1,985 dengan signifikan 0,027< 0,05. Hal ini berarti $\mathrm{T}$ hitung lebih besar dari $\mathrm{T}$ tabel dan signifikan $<0,05$ maka Ho diterima dan Ha ditolak, artinya variabel reliability (keandalan) berpengaruh signifikan terhadap loyalitas nasabah kredit komersil pada Bank Nagari Sumatera Barat Cabang Painan.

4. Berdasarkan hasil pengujian uji $\mathrm{T}$ untuk variabel responsiveness (daya tanggap) diatas dapat disimpulkan bahwa nilai $\mathrm{T}$ hitung responsiveness (daya tanggap) terhadap loyalitas nasabah sebesar 8,173 dan T tabel 1,985 dengan signifikan $0,000<0,05$. Hal ini berarti $\mathrm{T}$ hitung lebih besar dari $\mathrm{T}$ tabel dan signifikan $<0,05$ maka Ho diterima dan Ha ditolak, artinya variabel responsiveness (daya tanggap) berpengaruh signifikan terhadap loyalitas nasabah kredit komersil pada Bank Nagari Sumatera Barat Cabang Painan. 
5. Berdasarkan hasil pengujian uji $\mathrm{T}$ untuk variabel assurance (jaminan) diatas dapat disimpulkan bahwa nilai $\mathrm{T}$ hitung assurance (jaminan) terhadap loyalitas nasabah sebesar 0,983 dan $\mathrm{T}$ tabel 1,985 dengan signifikan 0,328 > 0,05 . Hal ini berarti $\mathrm{T}$ hitung lebih kecil dari $\mathrm{T}$ tabel dan signifikan $>0,05$ maka Ho ditolak dan Ha diterima, artinya variabel assurance (jaminan) berpengaruh tidak signifikan terhadap loyalitas nasabah kredit komersil pada Bank Nagari Sumatera Barat Cabang Painan.

6. Berdasarkan hasil pengujian uji $\mathrm{T}$ untuk variabel empathy (empati) diatas dapat disimpulkan bahwa nilai $\mathrm{T}$ hitung empathy (empati) terhadap loyalitas nasabah sebesar $-2,615$ dan $\mathrm{T}$ tabel 1,985 dengan signifikan 0,011 $<0,05$. Hal ini berarti $\mathrm{T}$ hitung lebih besar dari $\mathrm{T}$ tabel dan signifikan $<0,05$ maka Ho diterima dan $\mathrm{Ha}$ ditolak, artinya variabel empathy (empati) berpengaruh signifikan terhadap loyalitas nasabah kredit komersil pada Bank Nagari Sumatera Barat Cabang Painan.

7. Berdasarkan hasil pengujian uji $\mathrm{T}$ untuk variabel tangible (berwujud) diatas dapat disimpulkan bahwa nilai $\mathrm{T}$ hitung tangible (berwujud) terhadap loyalitas nasabah sebesar 2,791 dan T tabel 1,985 dengan signifikan 0,006 < 0,05 . Hal ini berarti $\mathrm{T}$ hitung lebih besar dari $\mathrm{T}$ tabel dan signifikan $<0,05$ maka Ho diterima dan Ha ditolak, artinya variabel tangible (berwujud) berpengaruh signifikan terhadap loyalitas nasabah kredit komersil pada Bank Nagari Sumatera Barat Cabang Painan.

\section{3. $\mathbf{U j i}\left(\mathbf{R}^{2}\right)$}

\section{Tabel 5}

Hasil Uji $\left(\mathrm{R}^{2}\right)$

Model Summary

\begin{tabular}{|l|l|l|l|l|l|}
\hline Model & $\mathrm{R}$ & R Square & $\begin{array}{l}\text { Adjusted } \\
\text { R Square }\end{array}$ & $\begin{array}{l}\text { Std. Error of } \\
\text { the Estimate }\end{array}$ & Durbin-Watson \\
\hline 1 & $.792^{\mathrm{a}}$ & .628 & .598 & 1.052 & 1.342 \\
\hline
\end{tabular}

a. Predictors: (Constant), X7, X6, X2, X3, X5, X4, X1

b. Dependent Variable: Y

Sumber : data olahan 2018

Dari tabel maka ringkasan hasil kolerasi dan determinasi adalah sebagai berikut :

1. $R=0.792$ berarti nilai kolerasi berada antara tidak berada antara 0,41 sampai dengan 0.71 berarti dari mutu pelayanan (X1) kepuasan pelanggan (X2),reliability (keandalan) (X3), responsiveness (daya tanggap) (X4), assurance (jaminan) (X5), empathy (empati) (X6), tangible (X7) terhadap loyalitas nasabah (Y) tidak memiliki keeratan yang kuat.

2. Adjusted R Square $=0.598$ berarti $59.8 \%$. Loyalitas nasabah kredit komersil pada Bank Nagari Sumatera Barat Cabang Painan dipengaruhi oleh mutu pelayanan, kepuasan pelanggan, reliability (keandalan), responsiveness (daya tanggap), assurance (jaminan), empathy (empati), tangible (berwujud) sedangkan sisanya 40,2\% dipengaruhi oleh variabel lainnya selain model yang diteliti dalam penelitian ini seperti pengaruh promosi, produk, citra perusahaan dan lain sebagainya. 


\section{SIMPULAN}

Berdasarkan hasil penelitian kepada nasabah kredit komersil pada Bank Nagari Sumatera Barat Cabang Painan yang berjumlah sebanyak 95 responden, maka dapat ditarik beberapa kesimpulan sebagai berikut :

1. Mutu Pelayanan berpengaruh positif dan tidak signifikan terhadap loyalitas nasabah kredit komersil hal ini dilihat dari nilai thitung $(805)<\mathrm{t}$ tabel $(1,985)$

2. Kepuasan Pelanggan berpengaruh positif dan tidak signifikan terhadap loyalitas nasabah kredit komersil hal ini dilihat dari nilai thitung $(218)<\mathrm{t}$ tabel $(1,985)$

3. Reliability (Keandalan) berpengaruh positif dan signifikan terhadap loyalitas nasabah kredit komersil hal ini dilihat dari nilai thitung (2.254) > t tabel $(1,985)$

4. Responsiveness (Daya Tanggap) berpengaruh positif dan signifikan terhadap loyalitas nasabah kredit komersil hal ini dilihat dari nilai thitung $(8.173)>\mathrm{t}$ tabel $(1,985)$

5. Assurance (Jaminan) tidak berpengaruh positif dan tidak signifikan terhadap loyalitas nasabah kredit komersil hal ini dilihat dari nilai thitung $(983)<\mathrm{t}$ tabel $(1,985)$

6. Empati (Empathy) berpengaruh negatif dan signifikan terhadap loyalitas nasabah kredit komersil hal ini dilihat dari nilai thitung $(-2.615)>\mathrm{t}$ tabel $(1,985)$

7. Tangible (Berwujud) berpengaruh positif dan signifikan terhadap loyalitas nasabah kredit komersil hal ini dilihat dari nilai thitung $(2.791)>t$ tabel $(1,985)$

\section{UCAPAN TERIMA KASIH}

Dalam penysunan skripsi ini penulis banyak mendapatkan bantuan dan dukungan moril maupun materil dari berbagai pihak. Untuk itu penulis mengucapkan terima kasih kepada :

1. Bapak Febryandhie Ananda, SE, M.Si selaku Ketua STIE “KBP” Padang.

2. Ibu Lidya Martha, SE, MM selaku Wakil Ketua STIE "KBP” Padang.

3. Ibu Febsri Susanti, SEI, MM selaku Ketua Program Studi Manajemen STIE "KBP" Padang.

4. Ibu Maria Magdalena, Spd, MM selaku Penasehat Akademik Program Studi Manajemen STIE “KBP” Padang.

5. Bapak Alfian, SE, MM selaku Dosen Pembimbing penulis yang telah bersedia meluangkan waktu, tenaga dan pikirannya dalam membimbing dan mengarahkan penulis dari awal penulisan skripsi sampai saat sekarang ini, sehingga penulis dapat menyelesaikan skripsi ini. Terima kasih atas segala kesempatan yang Bapak berikan semoga nasehat-nasehat yang Bapak berikan memberi manfaat bagi penulis selamanya.

6. Ibu Riri Mayliza, SE, MM dan Ibu Febsri Susanti, SEi, MM selaku Dosen Penguji penulis, terima kasih telah meluangkan waktunya.

7. Bapak-bapak, Ibu-ibu seluruh karyawan/I sekretariat dan perpustakaan STIE "KBP" Padang yang telah banyak membantu memberikan informasi kepada penulis demi kelancaran penulisan skripsi. 
8. Semua pihak yang tidak dapat penulis sebutkan satu persatu yang telah membantu penulis hingga terselesaikan skripsi ini.

\section{DAFTAR PUSTAKA}

Ayu, G., Ratih, P., Dewi, K., Nyoman, N., Yasa, K., \& Sukaatmadja, P. G. (2014). Pengaruh Kualitas Pelayanan Terhadap Kepuasan Dan Loyalitas Nasabah Pt Bpr Hoki Di Kabupaten Tabanan, 5, 257-275.

Dona, E. (2018). Kepuasan Publik Dilihat Dari Kualitas Pelayanan Dalam Pengurusan Perizinan (Kasus Badan Pelayanan Perizinan Terpadu, Pengadaan Barang Dan Jasa Kab. Dharmasraya). Https://Doi.Org/10.31227/Osf.Io/8cjhg

Estiningsih, A. W. (2013). Pengaruh Customer Relationship Management Terhadap Loyalitas Ibu Hamil Pada Pelayanan Persalinan ( Studi Di Rs Hermina Tangkubanprahu Malang ), 11.

Febrianingtyas, M., Arifin, Z., Fanani, D., Administrasi, F. I., \& Brawijaya, U. (N.D.). Pengaruh Customer Relationship Management Terhadap Kepuasan Dan Loyalitas Nasabah ( Survey Pada Nasabah Bank Jawa Timur Cabang Gedung Inbis Malang ), 9(2), 1-10.

Fernandes, Y. D., \& Marlius, D. (2018). Peranan Customer Service Dalam Meningkatkan Pelayanan Kepada Nasabah Pada PT. Bank Pembangunan Daerah Sumatera Barat Cabang Utama Padang. https://doi.org/10.31227/osf.io/wrh3p

Fernos, J., \& Putra, Y. E. (2019). Analisa Pengaruh Kualitas Pelayanan Terhadap Kepuasan Nasabah Pada PT. Bank Mega Syari'ah Padang. https://doi.org/10.31219/osf.io/y2baf

Imasari, K., \& Nursalin, K. K. 2011. "Pengaruh Customer Relationship Management Terhadap Loyalitas Pelanggan Pada Pt Bca Tbk". Jurnal Fokus Ekonomi, Vol. 10, No. 3 Hal. 183-192.

Kasanah, S. N. U. R., Syariah, J. P., Ekonomi, F., \& Bisnis, D. A. N. (2016). Pengaruh Kualitas Pelayanan Terhadap Loyalitas Nasabah Tabungan Btn Batara Ib Pada Bank Tabungan Negara Syariah Surakarta.

Kusnadi, A. M. (1945). Analisis Customer Relationship Management Dan Service Quality Terhadap Customer Value Melalui Customer Satisfaction Pada Bank, 6(April 2010).

Maidi. 2015. "Pengaruh Customer Relationship Management Terhadap Loyalitas Pelanggan Pada Pt Moga Djaja Di Surabaya. Jurnal Ilmu \& Riset Manajemen. Vol 3 No 8.

Marlius, D. (2017). Keputusan Pembelian Berdasarkan Faktor Psikologis Dan Bauran Pemasaran Pada PT. Intercom Mobilindo Padang. Jurnal Pundi. Volume 1. No. 1. Hal. 57-66. https://doi.org/10.31575/jp.v1i1.9

Marlius, D. (2016). Pengaruh Bauran Pemasaran Jasa Terhadap Minat Nasabah Dalam Menabung Pada Bank Nagari Cabang Muaralabuh. https://doi.org/10.31227/osf.io/vdqgx

Marlius, D. Putriani, I. (2019). Kepuasan Nasabah PT. Bank Rakyat Indonesia Unit Tapan Cabang Painan Dilihat dari Kualitas Layanan Customer Service. Jurnal Pundi. Volume 3. No. 2. Hal.111-122. https://doi.org/10.31575/jp.v3i2.151 
Marlius, D. Ananda, F. (2019). Pengaruh Kualitas Pelayanan Website Akademik Terhadap Minat Kuliah di AKBP Padang. Jurnal Pundi, Vol. 03, No. 03. Hal. 191-204. https://doi.org/10.31575/jp.v3i3.190

Marlius, D. (2018). Loyalitas Nasabah Bank Nagari Syariah Cabang Bukittinggi Dilihat Dari Kualitas Pelayanan. Jurnal Pundi. Volume 1. No. 3. Hal.12-22. https://doi.org/10.31575/jp.v1i3.60

Marlius, D. (2018). Pengaruh Dimensi Kualitas Pelayanan Website Akademik Terhadap Kepuasan Mahasiswa Pada STIE “KBP”. Jurnal Ipteks Terapan. Volume 12. No. 2. Hal. 116-128. http://doi.org/10.22216/jit.2018.v12i2.633

Marlius, D. RD Putra. (2018). Strategi Pengembangan Sulam Bayang. Jurnal Benefita: Ekonomi Pembangunan Manajemen Bisnis Dan Akuntansi. Volume 3. No. 2. Hal. 204-218. http://doi.org/10.22216/jbe.v3i2.3494

Mayliza, R. (2019). Analisis Customer Satisfaction Dan Behavioral Intention Dilihat Dari Service Quality, Food Quality Dan Price/Value Di Restoran Mc Donald's Depok. https://doi.org/10.31219/osf.io/e2jrt

Pengaruh, A., Relationship, C., Manajemen, J., Ekonomi, F., Bisnis, D. A. N., \& Hasanuddin, U. (2015). Analisis Pengaruh Customer Relationship Management (Crm) Terhadap Loyalitas Nasabah Pada Pt. Bank Bni Cabang Makassar.

Program, M., Ilmu, D., Ekonomi, F., \& Surabaya, U. (2015). Pengaruh Kualitas Layanan, Dan Customer Relationship Management Terhadap Kepuasan Pasien Dan Loyalitas Pasien Di Rumah Sakit Tingkat Ii Tentara Nasional Indonesia, 2(2).

Putra, Y. E., \& Aziz, N. (2019). Pengaruh Kualitas Pelayanan Dan Kepuasan Pelanggan Terhadap Loyalitas Nasabah PT. Bank Rakyat Indonesia Cabang Padang. https://doi.org/10.31219/osf.io/hcsw2

Ridwan, M. (N.D.). Muhammad Ridwan, Manajemen Baitul Maal Wa Tamwil (Bmt), (Yogyakarta: Uii Press, 2004) Hal.126 1, 1-94.

Santoso, S., \& Oetomo, H. W. (2013). Pengaruh Kualitas Pelayanan Terhadap Loyalitas Pelanggan, 2(6).

Sugiyono. (2015). Statistik Nonparametris Untuk Penelitian. Book. Bandung: Cv. Alvabeta.

Susanti, F. W Ekazaputri. (2018). Service Performance Dan Kepuasan Sebagai Moderating Variabel Terhadap Loyalitas Nasabah Pada PT BPR Labuh Gunung Payakumbuh Jurnal Benefita: Ekonomi Pembangunan Manajemen Bisnis Dan Akuntansi. Volume 3. No. 3. Hal. 433444.http://doi.org/10.22216/jbe.v3i3.3472

Wibowo, I. (2015). Pengaruh Kualitas Pelayanan Dan Kepercayaan Terhadap Loyalitas Nasabah Pt Bank Mandiri, Tbk, 3(3).

Widodo, B. H., \& Susanti, F. (2019). Pengaruh Human Relation (Hubungan Antar Manusia), Lingkungan kerja Terhadap Etos Kerja karyawan (Studi Kasus Pada PT. Pelindo Teluk Bayur Padang). https://doi.org/10.31227/osf.io/dxm8a 